\title{
TRAUMA PASCA TSUNAMI DALAM NOVEL TE O TORIATTE KARYA AKMAL NASERY BASRAL: PENDEKATAN PSIKOANALISIS
}

\author{
Trauma Pascatsunami in the Novel Te O Toriatte \\ By Akmal Nasery Basral: A Psychoanalysis Approach \\ Rini Widiastuti \\ Balai Bahasa Provinsi Jawa Barat \\ Jalan Sumbawa Nomor 11, Bandung 40113 \\ E-mail: riniwidi2275@gmail.com
}

\begin{abstract}
The Aceh tsunami was a devastating disaster around the coast, hundreds of thousands of people died and were lost, their lost possessions.The Tsunami disaster left a deep trauma to the Meutia character who was told in Akmal Nasery Basral's novel Te O Toriatte. This paper reveals how meutia lived post-tsunami with trauma sustained by psychoanalysis approach using a descriptive method. Based on the analysis show that Meutia is traumatized and often hallucinates after facing the tsunami in Aceh, Japan, and leakages of nuclear reactors in Japan. Meutia also has a multiple personality.
\end{abstract}

Keywords: tsunami, trauma, multiple personalities

\begin{abstract}
Abstrak
Tsunami Aceh merupakan bencana yang meluluhlantakan wilayah sekitar pesisir pantai, ratusan ribu orang meninggal dan hilang, harta benda tak bersisa. Bencana Tsunami menyisakan trauma yang mendalam pada tokoh Meutia yang diceritakan dalam novel Te O Toriatte karya Akmal Nasery Basral. Tulisan ini mengungkapkan bagaimana Meutia menjalani hidup pascatsunami dengan trauma yang dideritanya melalui pendekatan psikoanalisis dengan menggunakan metode deskriptif. Hasil analisis menunjukkan bahwa Meutia mengalami trauma dan sering berhalusinasi setelah menghadapi peristiwa tsunami Aceh, Jepang, dan kebocoran reaktor nuklir di Jepang. Meutia juga menderita kepribadian ganda.
\end{abstract}

Kata kunci: tsunami, trauma, kepribadian ganda

\section{PENDAHULUAN}

Indonesia sebagai negara kepulauan pada posisi georafis, geologis, hidrolis, dan demografis merupakan negara rawan bencana (Nirwana, 2016). Hal itulah yang menyebabkan Indonesia rentan terhadap bencana alam. Setiap tahun ada saja kejadian gempa di wilayah Indonesia. Adapun pengertian bencana menurut Undang-Undang No.24 Tahun 2007 adalah peristiwa atau rangkaian peristiwa yang mengancam dan mengganggu kehidupan dan penghidupan masyarakat yang disebabkan baik oleh faktor alam dan'atau faktor nonalam maupun faktor manusia sehingga mengakibatkan timbulnya korban jiwa manusia, kerusakan lingkungan, kerugian harta benda, dan dampak psikologis (Persetujuan Bersama, n.d.) 
Pada tahun 2004 gelombang raksasa tsunami meluluhlantakan bangunan sepanjang pesisir pantai Banda Aceh. Tidak hanya Indonesia, Sri Lanka, India, Malaysia, dan beberapa negara tetangga lainnya bahkan sampai Afrika Selatan terkena terjangan gelombang tsunami. Tsunami tersebut menjadi tragedi kemanusian terbesar. Korban meninggal dunia mencapai ratusan ribu. Harta benda hilang dan meninggalkan dampak psikologis.

Meutia salah satu yang mengalami dampak kejiwaan tersebut. Meutia adalah tokoh dalam novel Te O Toriatte. Novel karya Akmal Nasery Basral ini mengisahkan seorang Meutia yang kehilangan keluarganya pada tragedi tsunami Aceh. Ayah, ibu, dan ketiga adiknya menjadi korban tsunami. Bahkan dirinya hampir saja tidak tertolong. Bajunya yang tersangkut pada sebuah kapal menyelamatkannya dari maut. Ketika itu usia Meutia empat belas tahun.

Kisah Meutia mendapat liputan media massa Internasional. Pemberitaan itu menarik perhatian sepasang suami-istri asal Jepang. Kemudian Meutia diangkat anak oleh sepasang suami istri asal Jepang. Mereka melihat Meutia mirip dengan anaknya. Mereka sangat menyayangi Meutia. Namun tujuh tahun kemudian terjadi tsunami di Jepang kemudian disusul dengan kejadian kebocoran reaktor nuklir. Jiwa Meutia kembali terguncang karena bencana itu menewaskan kedua orang tua angkatnya.

Di tengah gempuran memori masa lalu yang membawanya ke kondisi PTSD (PostTraumatic-Stress-Dissorder) akut, Meutia berjibaku mewujudkan cita-citanya menjadi Doktor Computer Engineering.

Menariknya adalah di satu sisi Meutia mengalami trauma yang cukup berat tetapi tidak menghentikan mimpinya menjadi ahli computer walau bergelut dengan trauma pascatsunami yang menimpanya dua kali, tsunami Aceh dan Tsunami Jepang yang dikenal triple disaster. Penulis tertarik membahas trauma pascatsunami yang dialami tokoh Meutia dalam novel Te O Toriatte dengan judul Trauma Pascatsunami dalam Novel Te O Toriatte Karya Akmal Nesery Basral. Metode yang digunakan dalam tulisan ini adalah metode deskriptif kualitatif.

Penelitian serupa telah dilakukan oleh I Gede Arya Surabhawa (Surabhawa, 2020) dalam tesisnya mengenai bentuk rekonstrusi trauma perang akibat konflik yang terjadi di Afganistan, relasi timpang Barat dan Timur, serta memahami konsep trauma dengan judul Kesadaran Ganda: Trauma Perang dalam Novel The Kite Runner. Hasil dari penelitiannya adalah berupa penyebab munculnya trauma dan bentuk-bentuk trauma yang dialami oleh tokoh Amir. Klimaks dari trauma yang dialami Amir menyebabkan kesadaran ganda.

Ahmad Zamzuri (Zamzuri, 2019) dalam tesisnya mengungkapkan ingatan traumatis menyebabkan guncangan psikologis dan upaya rekonsiliasi terhadap trauma untuk menjalani kehidupan secara alami dengan judul Memori, Trauma, dan Upaya Rekonsiliasi terhadap Trauma dalam Novel Laut Bercerita Karya Leili S. Chudori. Hasilnya menunjukkan bahwa kekacauan 1998 menjadi memori traumatis secara personal. Ingatan traumatis diilutrstrasikan dengan insiden penangkapan, penyekapan, dan penyiksaan terhadap mahasiswa aktivis oleh aparat militer. 
Penelitian lain dalam tesis tahun 2019 tentang trauma pasca perang di Afganistan, poligami salah satu isu traumatis yang terjadi dalam rumah tangga ditulis oleh Vitria Tito Fismatika (Fismatika, 2019) dengan judul Trauma dan Upaya Rekonsoliasi Tokoh Utama Perempuan dalam A Thousand Splendid Suns Karya Khalled Hosseini. Hasil penelitian mengungkapkan ada tiga kategori trauma yaitu trauma dalam keluarga, dalam kehidupan berumah tangga, dan trauma dalam perang. Sedangkan upaya rekonsiliasi cara berpikir ada empat cara yaitu forget and forgive, never forget and never forgive, never forget but forgive, dan forget but never forgive.

Zietha Arlamanda Asri (Asri, 2019) meneliti Upaya Rekonsiliasi Tokoh Dengan Trauma Dalam Novel The Farming Of Bones Karya Edwidge Danticat, trauma akibat pembantaian Parsley yang mengakibatkan mimpi buruk tokoh yang ada dalam novel tersebut. Namun akhirnya dapat berkonsiliasi dengan trauma.

Trauma dalam KBBI berarti keadaan jiwa atau tingkah laku yang tidak normal sebagai akibat dari tekanan jiwa atau cedera jasmani. Trauma muncul atau terjadi dalam diri seseorang karena pernah mengalami sebuah peristiwa treumatis yang membuat jiwanya tergoncang disertai dengan sulitnya menerima kejadian buruk tersebut menjadi bagian dari hidupnya. Kata trauma dalam bahasa Inggris dan bahasa Yunani, "wound" dan "trauma" awalnya memiliki makna luka atau cedera pada tubuh. Di kemudian hari, dalam dunia kedokteran atau psikologi terjadi perubahan makna yang dipengaruhi oleh Sigmund Freud. Istilah trauma dipahami bukan sebagai luka atau cedera pada tubuh atau raga, namun luka atau cedera pada jiwa atau pikiran atau mental seseorang. (Caruth, 1996:4)

Caruth juga mengemukakan bahwa trauma merupakan rekaman ingatan di masa lampau yang berisikan peristiwa traumatis yang membentuk memori yang bersifat kompleks dan cara kedatangannya yang tiba-tiba menjadikan suatu rangkaian peristiwa tersebut belum bisa dan sulit diterima sepenuhnya menjadi pengalaman hidup. (Caruth, 1996:4)

Seseorang yang mengalami trauma biasanya susah tidur, tegang, sulit berkonsentrasi dan ia merasa ada yang mengatur hidupnya bahkan yang bersangkutan kehilangan makna hidupnya. Orang yang mengalami traumatik berada pada keadaan stres yang berkepanjangan yang dapat berakibat munculnya gangguan otak (Hatta, 2016:19)

Peristiwa traumatik yang muncul secara terus menerus dapat menimbulkan PTSD akut. Di samping faktor peristiwa traumatik, faktor lain yang memicu PTSD adalah ketidakberdayaan individu (Goleman, 1995) misalnya orang yang kena jambret atau ditodong pisau tanpa bisa melawan untuk membela diri. Faktor ketiga yang memicu PTSD adalah rasa takut.

\section{PEMBAHASAN}

Peristiwa yang mewarnai kehidupan ada yang menggembirakan sehingga dapat diterima oleh memori sebagai sesuatu yang indah untuk dikenang. Namun ada peristiwa yang terjadi dengan tiba-tiba dan tidak terduga yang membuat luka hati sehingga sulit 
untuk diterima. Peristiwa yang menjadikannya trauma. trauma yang dialami Meutia sebagai tokoh utama dalam novel Te O Toriatte karya Akmal Nasery Basral. Meutia adalah seorang perempuan dewasa berusia 28 tahun kelahiran Aceh yang pernah mengalami beberapa kali peristiwa dahsyat yang menyisakan trauma bagi jiwanya. Pertama saat usianya baru 14 tahun tsunami Aceh memporak-porandakan kampungnya dan kehilangan keluarganya, kemudian pada tahun 2011 kembali Meutia mengalami peristiwa yang membuatnya merasakan kembali luka yang belum kering. Tsunami Jepang merenggut kedua orang tua angkatnya. Bermula dari peristiwa yang dahsyat secara tiba-tiba yaitu tsunami yang terjadi pada tahun 2004 di Aceh Darussalam. Meutia hidup bersama emak, bapak, dan ketiga adiknya. Tsunami terjadi pagi-pagi ketika mereka hendak sarapan. Tiba-tiba tanah bergoyang, orang-orang mulai panik dikarenakan gempa yang cukup kuat. Pekikan takbir bersahutan. Ada pula yang meneriakan kiamat karena situasi dan kondisi yang menakutkan. Air laut surut. Ikanikan berserakan di bibir pantai. Langit gelap. Kemudian orang-orang sudah tidak peduli lagi dengan keadaan sekitar. Mereka berlari berusaha menyelamat diri. Seperti tergambar dalam kutipan berikut.

\footnotetext{
"Untuk sejenak Meutia tak menyadari apa yang terjadi saat melihat ratusan orang berlari bersamaan ke arahnya, seakan-akan mereka peserta lomba lari yang baru dilepas Wali Kota dari titik start di tepi pantai. Dia baru mengerti setelah mendengar jerit histeris bersahut-sahutan. "laut naik! Menjauh! Menjauh! Selamatkan diri!"

Sayup-sayup suara gemuruh menyeramkan terdengar menggelegar seperti raungan sekumpulan pesawat tempur yang sangar. Tidak. Bukan seperti itu. ini jenis suara yang belum pernah dia dengar sebelumnya, tak bisa digambarkan dengan kata-kata. (Basral, 2019:26).
}

Meutia tetap menunggu adik bungsunya yang terpisah dari kumpulan. Saat terlihat Ilyas, ia mengerahkan segenap kemampuannya untuk menyelamatkan adiknya tetapi ia tak bisa melawan keadaan yang tak pernah dibayangkan itu.

\footnotetext{
"Meutia melihat Ilyas lari terengah-engah bersama kerumunan massa mendekatinya... "yassss!" Meutia berseru sekuat tenaga sambil melambaikan tangan. Ilyas melihat dan membalas melambaikan tangan.... Meutia mengeluarkan seluruh kemampuan berlari sambil mencengkeram tangan adiknya. Dari belakangnya terdengar raungan bunyi yang semakin mengerikan. Meutia menoleh: langit tak terlihat, terhalang bukit air yang seolah memburunya dan orang-orang yang berlarian itu.bukit tapi air. Air tapi bukit. Dan bukit itu terus bergerak, melaju, mendekat! Menghantam apa pun yang ada di depannya! Membuat orang-orang berjatuhan, bergelimpangan, sebelum lenyap dari pandangan siapa pun yang masih bisa melihat pemandangan sangat mengerikan itu" (Basral, 2019:27).
}

Gambaran kedahsyatan peristiwa itu membuat jiwa Meutia terguncang. Bagaimana tidak, dalam sekejap semua keluarganya hilang termasuk Ilyas yang sempat ada dalam dekapannya. Meutia selamat karena bajunya tersangkut tiang kapal. Seperti tergambar dalam kutipan berikut.

\footnotetext{
"Asap tipis keluar dari dirinya, dari tubuhnya yang kaku tak bergerak. Asap itu membumbung naik dan berhenti pada ketinggian 20 meter dari permukaan tanah.... Meutia mengedarkan pandangan, sejauh mata memandang, untuk menyaksikan Banda Aceh yang hancur lebur. Mayat-mayat bergelimpangan dalam berbagai posisi. Ribuan jumlahnya. Kakek-nenek sepuh, orang dewasa dengan pakaian olahraga yang sedang lari pagi, bayi-bayi dalam dekapan ibu mereka agar tetap bersama sampai ajal menjemput. Meutia ingin menangis tetapi tak bisa karena dia hanya asap_-dan asap tak punya air mata" (Basral, 2019: 29).
} 
Meutia ditemukan oleh anggota tim penyelamat yang menyisir lokasi tersebut. Kemudian ia dibawa ke rumah sakit terdekat.setelah mendapatkan perawatan, tidak dijelaskan hari ke berapa, Meutia baru sadar. Dia menyebut, memanggil kedua orang tuanya, saat ditanya oleh dokter, suara Meutia tercekat.

\begin{abstract}
"Dia tak bisa meneruskan kalimat karena telinganya kembali dipenuhi raung gemuruh bukit air yang menderu-deru, mengejarnya dari belakang. Membuat tubuh Ilyas terlepas dari pelukannya. Memisahkan mereka selamanya.

Meutia merasa sangat bersalah karena tak bisa menjaga keselamatan adiknya. Kesadarannya menurun dengan pandangan semakin samar akibat dunia yang terlihat berputar. Sesayup telinganya mendengar kicau 'pii-uu' dari cempala kuneng yang terkenal itu. bertalu-talu di dalam kepalanya.... Dia kembali pingsan” (Basral, 2019:31).
\end{abstract}

Meutia kemudian diadopsi oleh sepasang suami istri dari Jepang. mereka kehilangan anak semata wayangnya dan ketika melihat Meutia ada kemiripan dengan anaknya. Meutia kemudian disekolahkan di Jakarta. SMA favorit waktu itu. meutia sangat diperhatikan oleh orang tua angkatnya. Selepas SMA Meutia akan tinggal di Jepang bersama orang tua angkatnya. Meutia anak yang cerdas. Dia kursus bahasa Jepang sebagai bekalnya. Akan tetapi bayangan-bayangan kedahsyatan peristiwa itu tak pernah hilang dari ingatannya. Rasa bersalah karena tak bisa menyelamatkan adiknya membayangi langkahnya menyebabkan Meutia berhalusinasi. Seperti kutipan di bawah ini.

"Ketika sampai di tengah, dia melihat Ilyas memperhatikannya dari arah kedatangan air. Wajah bocah lelaki itu melihat cemas seakan khawatir kakaknya terpeleset. Meutia mengangguk sebagai isyarat bahwa dia tidak apa-apa. Ilyas tersenyum lega sebelum bayangannya menghilang" (Basral, 2019:88).

Saat Meutia istirahat medengar seorang laki-laki bernyanyi. Hasrat ingin ikut bersenandung muncul. Namun rasa kantuk yang tak bisa ditahannya, dia memutuskan untuk tidur. Sasaat ia terlelap kemudian ia mimpi buruk. Peristiwa tsunami itu menggangunya.

"Meutia ingin ikut bersenandung, namun kantuknya terlalu berat dilawan sehingga dia pun terlelap seperti yang lain. lalu ombak tsunami itu menggulung tubuhnya, membuatnya merontaronta di dalam sleeping bag. Membuat napasnya tersengal" (Basral, 2019:90).

Kejadian itu dua tahun setelah peristiwa tsunami Aceh, September 2006. Hal itu menampakkan bahwa Meutia mengalami trauma. Dia melihat Ilyas ada di sekitar dia dan mengalami mimpi buruk. Meutia belum bisa menerima dengan ikhlas takdir yang menimpanya. Namun karena Meutia anak yang cerdas dan mendapatkan teman atau sahabat yang memperhatikan dia dan tentunya orang tua angkatnya yang memberi fasilitas terbaik, ia bisa melewatinya. Walau hidupnya masih diliputi trauma dan pendidikannya pun tidak terganggu. Bahkan ia mendapatkan beasiswa untuk kuliah di Jepang. Meutia tumbuh dewasa. Dia tidak ingin merepotkan orang tua angkatnya. Ia ingin membuat orang tua angkatnya bangga, karena baginya, merekalah yang ia miliki. Pada saat dia kelas XI, kakak tingkat dua tahun di atasnya manaruh hati pada Meutia. Namanya Tuta hingga pada kesempatan acara mendaki Pangrango Tuta tidak 
membuang kesempatan itu. pada awalnya Meutia tidak bersimpati kepada yang namanya Tuta. Di matanya, Tuta cowok songong. Namun saat tahu fakta bahwa Tuta ikut menjadi relawan pada peristiwa dua tahun lalu yang merampas seluruh keluarganya dan tahu tentang dirinya adalah lulusan terbaik di Tsanawiyah, Meutia mulai tergoda untuk tahu lebih dekat lagi tentang cowok yang kesan pertamanya tidak begitu baik.seperti digambarkan dalam kutipan di bawah ini.

\footnotetext{
“Relawan? Relawan tsunami di Aceh maksudnya?” nada suara Meutia masih tidak percaya. "Bang Tuta nggak bohong?" lanjutnya dengan mata menyelidik setajam pandangan jaksa di persidangan.

"Gue akan disambar geledek saat ini kalau bohong!" jawab Tuta tegas. "Kisah selamatnya lo jadi topik obrolan para relawan. Dan gue beruntung bisa melihat lo di RS meski hanya sebentar karena lo saat itu masih sering pingsan. Gue nggak pernah lupa apa yang gue lihat saat itu. seorang cewek ringkih, nggak gue kenal, tapi entah kenapa membuat perasaan gue langsung ingin melindunginya, menyuapinya, menunggunya sampai siuman” (Basral, 2019:110).
}

Mendengar cerita Tuta, kakak tingkatnya membangunkan ingatan peristiwa tsunami. peristiwa yang meluluhlantakan tempat tinggalnya dan sekaligus memisahkan ia dengan keluarganya. Keluarganya yang menjadi korban amukan tsunami. Meutia terguncang jiwanya.

"Termasuk orangtua dan tiga adikku," potong Meutia yang akhirnya tak bisa menahan kesedihan yang bergolak di ulu hatinya, kilasan kenangan saat-saat terakhirnya bersama keluarga di Masjid Baiturrahim dan ketika ombak laut mengamuk, mengejar sampai ke darat. Kembali menyiksa benaknya. Tetes air mata yang awalnya hanya sebutir dengan cepat berubah menjadi aliran deras. betapa pun gadis itu berusaha mengendalikan emosinya dengan menangkupkan kedua telapak tangannya di wajah, badannya berguncang hebat" (Basral, 2019:112).

Setelah tahu fakta Tuta ada di tengah-tengah para penyintas tsunami Aceh saat itu dan kepedulian Tuta, Meutia merasa hatinya menghangat ketika Tuta menyatakan cintanya dan akhirnya Meutia menerima, berbagi cerita dengan Tuta. Hari-harinya penuh warna, hubungan mereka sangat membantu perkembangan kejiwaan Meutia. Dia merasa ada yang menyayangi, mencintai selain orangtua angkatnya karena mereka masih terpisah jarak. Sampai pada suatu ketika, Tuta yang panggilan sayang antara mereka berdua adalah Atte bermaksud mengenalkan Meutia kepada lingkungan keluarga Atte. Tak diduga Meutia penerimaan keluarga Atte sungguh menyakitkan. Maminya menyangkutpautkan bibit, bebet, bobot. Prestasi Meutia tidak cukup untuk diterima di kalangan keluarganya karena saat ditanya keturunan dari mana Meutia hanya mengatakan keluarganya habis menjadi korban tsunami dan kuliah dengan beasiswa di Jepang mengikuti orang tua angkatnya. Seperti kutipan di bawah ini.

"O, anak angkat ." mami mengambil alih pembicaraan dengan nada kecewa. "Di dalam keluarga kami, pertimbangan bibit, bebet, bobot, menjadi hal penting. Harus seimbang. Apalagi kalau sudah diundang untuk makan bersama seperti sekarang. meski bobot bagus, tapi bibit dan bebet tak jelas itu biasanya....'(Basral, 2019:147).

Meutia dipermalukan oleh orang tua kekasihnya. Meutia tidak nyaman lagi berada di situ. Bukan hanya maminya tapi adiknya pun perkataannya melukai hati Meutia.

"Bukan, saya tidak punya om atau tante. Saya tinggal dengan..." 
"Nah, apalagi tidak punya om atau tante. Parah!” Mami menggeleng-geleng. "Orang Timur seperti kita ini punya ciri sangat akrab dengan keluarga besar, tidak seperti orang Barat. Orang yang tidak akrab dengan keluarga besar itu biasanya karena tiga kemungkinan. Satu, sombong karena merasa lebih hebat dari familinya sehingga memilih tidak maubergaul dengan mereka. Dua, minder karena merasa familinya jauh lebih dari dia sehingga tidak mau bergaul dengan mereka. Tiga, sedang menjalani hukuman adat, dikucilkan, diberi sanksi untuk menyendiri. Nah,keluargamu termasuk yang mana, Meutia?"

"Ya, cuaca mendung deh. Bakal ada hujan besar nih. Nggak asyik," sindir Naning sambil bersendawa yang membuat Mami mendelik, "Kamu itu keturunan keraton tapi nggak punya etiket sih, Ning?" (Basral, 2019:148).

Fakta lain yang baru diketahui Meutia adalah Tatiana, wanita yang disebut maminya Tuta yang lebih pantas untuk Tuta.pukulan lagi buat Meutia. Perlakuan maminya Tuta membuat luka dan menjadi ingatan yang membekas menjadikan Meutia tidak mudah untuk membuka diri, percaya pada orang lain dalam hal hubungan yang serius. Seperti dalam kutipan d bawah ini.

“...coba bandingkan kawanmu ini dengan sepupumu, Tatiana, yang juga baru lulus SMA meski ketinggalan dua tahun karena sibuk syuting. Dia lebih cantik, terkenal, dan sudah punya penghasilan sendiri sebagai aktris sinetron. Silsilah keluarganya juga jelas dan sama-sama berdarah keraton seperti kita!" (Basral, 2019:150).

Selepas itu Meutia melanjutkan studi di Jepang dan hidup bersama haha (ibu) dan chichi (ayah). Dia tidak lagi terlarut pada kenyataan bahwa tak mungkin merajut mimpi dengan orang yang dicintainya, Atte. Meutia akan merancang hidup baru di Fukushima. Satu sisi kedewasaan seorang penyintas yang belum tuntas dengan masalah trauma yang kerap membayangi.

"Sebentar lagi, ke mana pun mataku menatap, yang akan sering terlihat hanya huruf kanji. Setiap kali perutku lapar, yang tersaji hanya kuliner Negeri Putra Matahari. Tayangan TV dan radio yang menggempur panca indraku disampaikan dalam bahasa buku. Air yang kuminum berasal darimata air dan telaga dari berbagai penjuru Negeri Sakura. Maka aku harus benar-benar memahami di luar kepala segala hal yang berkaitan dengan Jepang, terutama wilayah Fukushima tempatdi mana masa depan kurancang" (Basral, 2019:128).

Meutia dihujani cinta dan kasih sayang ayah dan ibu angkatnya yang selama empat tahun menanti kedatangan Meutia. Meutia diperlakukan seperti halnya anak kandungnya sendiri.

"Ibu angkatku, Harumi, memelukku ketat. Dia menangis bahagia seakan-akan aku adalah Reiko, anak kandungnya yang hidup lagi. "Puji Tuhan, akhirnya kau sampai juga di sini, anakku," katanya sambil menciumi hijab dan pipiku berulang kali. Ayah angkatku, Hiroshi Mishima, merangkul istrinya dan aku sekaligus. "empat tahun penantian yang menguji kesabaran akhirnya terbayarkan hari ini." katanya dengan suara bergetar menahan keharuan. Sungguh hari itu aku merasakan lagi bagaimana nikmatnya memiliki orang tua . Tuhan sungguh baik memberiku kesempatan kedua untuk memiliki ayah dan ibu. Kesempatan yang tak dialami semua orang (Basral, 2019:129).

Untunglah di rumah, Haha dan Chichi betul-betul memanjakanku" (Basral, 2019:131).

Berkat kasih sayang Haha dan Chichi, emosi dan ingatan masa lalu tidak lagi mengganggu Meutia. Dia bahagia dan merasa beruntung Tuhan telah berikan orang tua angkat yang sangat baik. Sampai pada suatu hari, Haha mengajaknya jalan-jalan ke Taman Kerajaan Oyakuen yang merupakan tempat pemakaman para pemimpin kerajaan 
pada masa itu. Di sana bayangan tsunami muncul. Ingatan kepedihan itu manari-nari di kepalanya.

"Aku pernah begitu dekat dengan kematian ketika digulung tsunami Aceh. Tetapi berada di dekat makam-makam itu menimbulkan sensasi ngeri tersendiri yang membuat bulu kudukku berdiri. Ada suasana mencekam dan menakutkan yang kurasakan, seakan-akan para penghuni makam adalah korban tsunami-bukan byakkotai-yang terjebak dalam perangkap dinding raksasa. Mataku melihat Bapak, Mak, serta ketiga adikku Malahayati, Maisarah, dan Ilyas, terbujur kaku di makam dengan berliter-liter air laut yang memadar di dalam perut mereka. Makam-makam lainnya penuh mayat korban tsunami dengan posisi serupa satu liang disesaki kumpulan jenazah" (Basral, 2019:133).

Belum hilang rasa takutku melihat pemandangan mengerikan itu mendadak dari langit mayat mayat berjatuhan, Seperti permainan Tetris, hanya saja tidak terjadi penumpukkan mayat ke atas. Mayat yang baru jatuh melesakkan mayat yang ditimpanya menjadi terbenam lebih dalam sehingga posisi mayat paling atas tetap tidak melebihi tinggi makam. Di sini aku menjerit histeris nyaliku mengempis habis. "Haha aku takut sekali," ujarku sambil memeluknya gemetar. “bisakah kita pergi dari sini?”(Basral, 2019:133).

Ingatan masa lalu saat dia melihat ribuan mayat menumpuk dimana-mana diasosiasikan dengan deretan makam yang ia kunjungi bersama Haha. Trauma yang begitu dalam. Sepulang dari Oyakuen Meutia sering mengalami mimpi buruk. Meutia melihat mayatmayat berjatuhan dari langit seperti hujan memenuhi halaman rumah, kampus, di tempat tidur kemudian terbagun dan akhirnya gelisah dan sulit tidur. Keberadaan Haha sangat berarti. Ia menenangkan saat Meutia gelisah. Diusapnya, dipeluk, dan diciumnya. Curahan perhatian Haha dan Chichi menjadikan jiwanya dipenuhi kebahagiaan. Namun beberapa tahun kemudian tragedi tsunami kembali mengguncang jiwa Muetia. Tepatnya tahun 2011 Jepang diterjang tsunami, gempa dan kebocoran reaktor nuklir. Yang menjadi pukulan teramat besar adalah bahwa kedua orang tua angkatnya menjadi korban tsunami. Pertahanan Meutia kali ini tak terbendung. Meutia protes terhadap Tuhan. Mengapa dia ditimpa bencana seperti ini sampai dua kali. Tsunami merenggut kebahagiaannya, mengambil orang-orang yang ia cintai. Meutia mengalami depresi. Dia tidak lagi melakukan salat sebagai kewajiban seorang hamba, bahkan hijabnya sempat dibuka. Hal itu karena kepedihan hidup bahwa tak ada lagi orang yang ia cintai dan mencintainya. Tuhan menurutnya tidak adil.

"Terus terang saat itu dalam hati aku sangat marah kepada Tuhan. Marah sekali. Apa kesalahan besar yang kuperbuat di dalam hidupku sehingga Tuhan menurunkan dua kali bencana dahsyat yang merenggut kehidupan orang-orang yang kucintai? Aku tidak suka dengan cara Tuhan. Aku bahkan akan melawan-Nya terang-terangan" (Basral, 2019:185).

Setelah kejadian tsunami disusul gempa dan beberapa hari kemudian terjadi kebocoran reaktor nuklir. Suara yang memekakkan telinga itu membuat Meutia syok berat. Narator pun menegaskan bahwa Meutia sempat melakukan protes frontal dengan tidak melakukan ibadah.

"Ada saat-saat di mana dia melakukan protes frontal kepada Sang Maha Pencipta dengan meninggalkan ibadah dang memilih gaya hidup sebagai freelance monotheist, Tetap percaya kepada Tuhan Yang Maha Esa namun tidak mengidentifikasikan diri pada satu agama manapun" (Basral, 2019: 43). 
Dalam keadaan demikian, datanglah Ryoichi Yamaoka. Dia adalah seorang ahli genom. Dia yang sangat intens memberi perhatian kepada Meutia. Awalnya dia tertarik karena Meutia seorang penyintas yang mengalami dua kali tsunami. Perkenalannya dengan Ryo sudah berjalan tiga tahun. Ryo sangat menginginkan Meutia mau menerima lamarannya. Namun Meutia belum bisa percaya apakah Ryo atau siapa pun bisa hidup dengan seorang yang punya gangguan PTSD, trauma yang bisa datang kapan saja.

\footnotetext{
"Meutia menghembukan napas berat. Suaranya kembali sedih, "Kamu tahu aku mengidap PTSD, Post Traumatic Stress Disorder, sampai sekarang belum sembuh meski sudah menjalani berkalikali sesi terapi. Aku hanya akan menjadi beban bagi siapa pun yang dekat denganku. Apalagi jika sampai menikah," tuturnya hambar. "Kamu tak akan bisa menghadapinya dalam jangka panjang, meski untuk jangka pendek mungkin kau bisa tahan menghadapiku. Semalam aku mengalami mimpi lagi, sehingga aku kembali tergantung pada benzo" (Basral, 2019:45).
}

Awal tahun 2019 mereka sedang ada di Indonesia. Meutia ada penelitian mengenai tsunami yang terjadi di lampung dan Ryo akan menjadi pembicara di Bali. Ryo meyakinkan bahwa trauma yang diderita Meutia dapat disembuhkan dengan rekayasa genetika. Sejak kehilangan orang tua angkatnya Meutia memang mengalami masa-masa sulit karena dia benar-benar hidup sendiri. Sering berhalusinasi. Kehadiran Ryo setidaknya sudah mengembalikan keyakinannya kepada Tuhan.

Tanpa diduga keberadaan Meutia di Jakarta diketahui oleh Tuta, mantan kekasihnya sepuluh tahun lalu. Pertemuan pun dirancang Tuta dengan sesi wawancara untuk acara TV karena Tuta menjadi penyiar salah satu stasiun TV. Kenangan masa lalu pun terkuak kembali. Pada sesi terakhir, Meutia meminta bicara empat mata dengan Atte. Meutia mulai membuka dengan obrolan tentang terakhir kejadian diantara mereka. Namun di tengah obrolan, saat tahu bahwa Atte telah menikah dengan Tatiana, Meutia merasakan sakit kepala dan langsung mencari teman imajinasinya, Zac. Setiap dia mimpi buruk ataupun kepalanya berdenyut, Zac menjadi penasehatnya untuk segera mengonsumsi alodorm dan Prazosin, obat penenang. Tak lama berselang Meutia membenturkan kepalanya ke jendela dan ketika Tuta akan mencegahnya, Tuta heran dengan perubahan Meutia dengan pribadi yang lain.

“Apa yang kamu lakukan, Mut?" Tuta menarik tangan gadis itu dengan maksud menjauhkan badannya dari jendela tapi justru ditepis Meutia dengan kasar. "Jangan sentuh aku! Aku bukan Meutia!” lanjutnya dengan mata melotot. “Aku adalah Reiko Mishima!” (Basral, 2019:157).

Karena kejadian itu yang menghantarkan Meutia bertemu dengan teman-teman sekelasnya waktu SMA. Tuta kebingungan melihat perubahan Meutia. Tuta membawa Meutia ke tempat Farhan, Psikiater terkenal, teman sekelasnya dulu. Malamnya Tuta melamar Meutia. di tengah kondisinya yang mengidap trauma akut dan kepribadian ganda, Meutia harus memberi jawaban siapa yang akan dipilihnya. Meutia pun meminta saran dari sahabat-sahabatnya. Tak terkecuali Farhan, Meutia meminta pandangannya. Alih-alih dapat simpulan siapa yang akan dipilihnya, Meutia semakin bingung karena kenyataan bahwa Farhan pun mencintainya dengan cara berbeda. Dari awal, Meutialah 
yang menjadi motivator Farhan menjadi psikiater dan kuliah di Jepang juga selain dia pun pernah mengalami trauma karena sempat menjadi korban pembunuhan oleh ibunya sendiri yang menderita skizofrenia akut. Setelah itu ibunya bunuh diri. Namun Farhan masih memiliki ayah yang mencurahkan kasih sayangnya sehingga Farhan bisa melanjutkan hidupnya. Sebelum mengetahui fakta bahwa ibunya Farhan menderita skizofrenia. Meutia berselancar di dunia maya untuk mengetahui fakta tiga lelaki yang mengaku mencintainya. Meutia sangat terpukul, hancur tak bersisa kala mengetahui Ryo menjadikannya proyek percobaan untuk meraih karier dan pengakuan dunia. Tuta ternyata maniak seks. Dalam keadaan rapuh seperti itu Meutia menghadirkan teman imajinasinya, Meutia hampir saja mengakhiri hidupnya dengan melompat dari jendela. Farhan segera datang bersama tiga karyawan hotel dan Kak Halimah, anaknya ibu kos Meutia. Meutia butuh kasih sayang yang tulus, butuh orang-orang yang mengenalnya dengan baik dan suasana rumah yang sudah akrab dengannya. Secara psikologis dengan begitu pemulihan kondisinya akan lebih cepat.

\section{SIMPULAN}

Meutia mengalami PTSD akut disebabkan peristiwa tsunami Aceh dan triple disaster. Peristiwa itu merenggut orang-orang yang dicintainya yakni keluarga dan orang tua angkatnya. Semakin terpukul saat mengetahui orang yang mengakui mencintainya ternyata hanya memanfaatkan dirinya. Jiwanya terguncang hingga ada dorongan untuk bunuh diri, melompat dari jendela hotel. Untungnya Farhan seorang psikiater, kawan semasa SMA-nya yang juga mencintainya menyelamatkan Meutia. Meutia membutuhkan pemulihan kondisinya secara psikologis, dengan berada ditengahtengah orang-orang yang dikenalnya dengan baik dan lingkungan yang tidak asing baginya membuat Meutia merasa nyaman dan aman. Hal itu penting bagi orang yang dalam masa pemulihan trauma. Sebagaimana judul novel ini Te $O$ Toriatte yang diterjemahkan menjadi "genggam cinta" walaupun musibah datang bertubi-tubi, selama tangan-tangan kita saling tergenggam maka kita akan saling menguatkan dengan cinta dan kasih sayang.

\section{DAFTAR PUSTAKA}

Asri, Z. A. (2019). Upaya Rekonsiliasi Tokoh Dengan Trauma Dalam Novel The Farming Of Bones Karya Edwidge Danticat. UGM.

Basral, A. N. (2019). Te O Toriatte. (D. R. Ramadhany, Ed.) (pertama). Jakarta: PT. Gramedia Pustaka Utama.

Caruth, C. (1996). Unclaimed Experience Trauma, Narrative, and History.

Fismatika, V. T. (2019). Trauma Dan Upaya Rekonsiliasi Tokoh Utama Perempuan Dalam A Thousand Splendis Suns Karya Khaled Hosseini.

Goleman, D. (1995). Emotional Intelligence. New York: Bantan Books.

Hatta, K. (2016). Trauma Dan Pemulihannya. Retrieved from dakwaharranirypress@yahoo.com

Nirwana, H. (2016). Konseling Trauma Pasca Bencana. Ta'dib, 15(2). 
https://doi.org/10.31958/jt.v15i2.224

Persetujuan Bersama, D. (n.d.). Presiden Republik Indonesia-2--Salinan-Dewan Perwakilan Rakyat Republik Indonesia Dan Presiden Republik Indonesia.

Surabhawa, I. G. A. (2020). Kesadaran Ganda: Trauma Perang Dalam Novel The Kite

Runner. UGM. Retrieved from http://digilib.fib.ugm.ac.id/book/detail/14990

Zamzuri, A. (2019). Memori, Trauma, Dan Upaya Rekonsiliasi Terhadap Trauma Dalam Novel Laut Bercerita Karya Leila S. Chudori. UGM.

\section{HASIL DISKUSI}

Tidak ada pertanyaan 